\title{
KOTIE ROODT-COETZEE SE BYDRAE TOT DIE KULTUURHISTORIESE MUSEUMWESE IN SUID-AFRIKA - DIE TRANSVAALMUSEUMFASE, 1933-1964
}

\author{
Elda Grobler en Fransjohan Pretorius \\ Departement Historiese en Erfenisstudies, Universiteit van Pretoria, \\ Pretoria 0002
}

\section{Kotie Roodt-Coetzee's contribution to cultural history museology in South Africa - the Transvaal Museum phase, 1933-1964}

This article highlights Kotie Roodt-Coetzee's contribution to cultural history museology in South Africa. Her interest in cultural history resulted in her first visit to the Old Museum in Boom Street, Pretoria (at that stage managed by the Transvaal Museum), where she found an exceptional collection of Afrikaner cultural objects. These were regarded as the history collection, as cultural history as an academic subject was in an early stage of development and not recognized as a museum subject on par with archaeology and anthropology. Many of the objects had been collected by the Staatsmuseum of the South African Republic. Roodt-Coetzee was concerned about the poor conditions that prevailed at the Old Museum, and raised the matter on several occasions. The fact that the public saw little of the collection was also a bone of contention. She made use of two opportunities to rectify this matter: objects from the collection were exhibited at the inauguration of the Voortrekker Monument in1949 and the Van Riebeeck Festival in 1952. After her appointment as curator at the Transvaal Museum in 1953 she planned and put up many new exhibitions, such as the display to commemorate the Centenary of Pretoria in 1955 and the well-known Cape Silver Exhibition in 1962. She succeeded in assembling an exceptional collection of cultural history objects, one of the largest in the country. She regarded the conservation of the collection and the detailed documentation of the objects as priorities. She also gave the necessary attention to the Old Museum, the Kruger House and the museum at the Voortrekker Monument. Her ideal of an independent cultural history section was realized with the establishment of the National Cultural History and Open-Air Museum in 1964.

Key words: Collection, conservation, Cultural History, cultural history museums, exhibitions, F.V. FitzSimons, museums, museolgy, Kotie Roodt-Coetzee, National 
Cultural History and Open-Air Museum, Old Museum Boom Street, Pretoria, restoration, Transvaal Museum, Voortrekker Monument

Hierdie artikel ondersoek Kotie Roodt-Coetzee se bydrae tot die kultuurhistoriese museumwese in Suid-Afrika. Haar belangstelling in kultuurgeskiedenis het gelei tot haar eerste kennismaking met die Ou Museum in Boomstraat, Pretoria (toe nog onder die bestuur van die Transvaalmuseum) en die uitsonderlike versameling Afrikanerkultuurvoorwerpe daar. Dié versameling, wat as die geskiedenisversameling bekend gestaan het, het uit die dae van die Staatsmuseum van die Zuid-Afrikaansche Republiek gedateer. Kultuurgeskiedenis as vak was nog in sy kinderskoene en is nie as museumdissipline op gelyke voet met antropologie en argeologie erken nie. By verskeie geleenthede het sy haar kommer oor die swak toestand van die voorwerpe uitgespreek en ook die feit dat die grootste gedeelte van die versameling onbekend aan die publiek was. Toe die geleentheid hom in 1949 by die onthulling van die Voortrekkermonument en in 1952 met die Van Riebeeckfees voordoen, het sy baie van die voorwerpe uitgestal. Na haar aanstelling as vakkundige beampte by die Transvaalmuseum in 1953 het sy talle nuwe uitstallings beplan en uitgevoer, onder meer die uitstalling ter viering van die Eeufees van Pretoria in 1955 en die bekende Kaapse silwer-uitstalling van 1962. Sy het haar nie slegs beywer vir die uitbou van die kultuurhistoriese versameling tot een van die omvangrykste in die land nie, maar ook vir die kundige bewaring en gedetailleerde dokumentering van die voorwerpe. Die Ou Museum, die Krugerhuis en 'n museum in die Voortrekkermonument het besondere aandag gekry. Haar ideaal vir die afskeiding van die kultuurhistoriese afdeling van die Transvaalmuseum as selfstandige museum is verwesenlik toe die Nasionale Kultuurhistoriese en Opelugmuseum in 1964 tot stand gekom het.

Sleutelterme: Bewaring, F.V. FitzSimons, museums, museumkunde, Kotie RoodtCoetzee, kultuurgeskiedenis, kultuurhistoriese museums, Nasionale Kultuurhistoriese en Opelugmuseum, Ou Museum Boomstraat, Pretoria, restourasie, Transvaalmuseum, uitstallings, Voortrekkermonument, versameling

\section{Inleidend}

Kotie Roodt-Coetzee (1913-2005) het as museumkundige 'n besondere bydrae tot die ontwikkeling van kultuurhistoriese museums in Suid-Afrika gelewer. Sy het haar loopbaan in 1953 by die Transvaalmuseum begin en was by haar aftrede in 1978 die direkteur van die Nasionale Kultuurhistoriese en Opelugmuseum. Sy het bekendheid verwerf vir haar onvermoeide ywer vir die insameling van kultuurvoorwerpe. Haar 
kundigheid het egter veel verder gestrek as haar onmiddellike werkkring, aangesien sy deur stadsrade, munisipaliteite en instansies geraadpleeg is oor die die ontwikkeling van plaaslike museums asook die uitstal, dokumentering en bewaring van voorwerpe. In 'n tydperk toe die kultuurhistoriese museumwese nog in 'n beginstadium was, was haar kennis en die voorligting wat sy ruimskoots gedeel het, belangrik.

\section{Kotie Roodt-Coetzee: belangstelling in kultuurvoorwerpe en museums}

Roodt-Coetzee se belangstelling in die Afrikaner se kultuurvoorwerpe is reeds as jong kind deur haar vader se vertellings van die pionierslewe van die Boere gestimuleer. Hoewel hy nie veel skoolonderrig ontvang het nie, het hy 'n buitengewone algemene kennis gehad. Hy het veral kennis van en liefde vir die Boerekultuur gehad, 'n toegeneentheid wat hy aan haar oorgedra het. Hy het haar vertel hoe hulle huise gebou, meubels gemaak en velle gebrei het. Die gesin het eers in die Wolmaransstadomgewing en later op die plaas Nooitgedacht in die distrik Bronkhorstspruit gewoon.

Reeds op 'n vroeë leeftyd het Roodt-Coetzee met die feit kennis gemaak dat'n museum 'n omskrewe doelstelling en 'n beplande werkswyse moet hê. Sy het al die jare twee koerante ${ }^{1}$ bewaar waarin 'n artikel verskyn het oor Die moderne museum en sy funksies deur E.C.N van Hoepen, direkteur van die Nasionale Museum in Bloemfontein. Van Hoepen het veral die destydse museumkrisis behandel wat, volgens hom, te wyte was aan die gebrek aan afbakening, die feit dat die doelstellings van baie museums nie bepaal was nie en hulle pligte ook nie omskryf was nie. Hoewel Van Hoepen op die natuurhistoriese museum gekonsentreer het, het hy wel melding daarvan gemaak dat daar ook twee groepe museums is "waarvan die een omvat die werke van die mens en die ander die produkte van die natuur." ${ }^{2}$ Volgens Van Hoepen kon 'n goedgeorganiseerde, kragtige en deeglike inrigting verkry word deur stelselmatige eksplorasie, byeenbring, bestudering van die produkte van die natuur, 'n samevatting van die resultate en die berging van die dokumente en materiaal. Juis hierdie duidelike uiteensetting van die grondliggende museumbeginsels, het RoodtCoetzee se oog gevang en sy het dié paragraaf gemerk. Van Hoepen het ook klem op bekendmaking en uitstalling gelê. Later jare sou dié beginsels weerspieël word in die doelstellings en funksies vir 'n kultuurhistoriese museum wat Roodt-Coetzee voorgestaan het.

Nasionale Kultuurhistoriese Museum (hierna NKM), Kotie Roodt-Coetzee Argief, Doos 54, Die Volksblad, 1926-05-01, p. 7 en 1926-05-04, p. 10.

2 NKM, Kotie Roodt-Coetzee Argief, Doos 54, Die Volksblad, 1926-05-01, p. 7. 


\section{Vroeë betrokkenheid by die Transvaalmuseum ${ }^{3}$}

As jong eerstejaarstudent in 1933 was Kotie Roodt (met haar huwelik met P.C. Coetzee in 1934 het sy haar nooiensvan by haar getroude van gevoeg) een van die min buitestanders wat die geleentheid gehad het om met die geskiedenisversameling in die Transvaalmuseum kennis te maak. Aanvanklik het sy as student by die Pretoriase Normaalkollege ingeskryf, maar het aan die Universiteit van Pretoria 'n bykomende kursus in Afrikaanse Kuns en Kultuur gevolg. Die vak is deur' $n$ besonder begaafde dosent, prof. M.L. du Toit, gedoseer wat sy studente, en dus ook vir Roodt, begeester het. Dié nuwe departement wat in 1931 ingestel is, moes "nou alle kragte inspan om 'n wetenskaplike inhoud aan die nuwe dissipline te gee," het sy later onthou. ${ }^{4}$ As eerstejaarstudent het sy 'n studie oor Boerekrygsgevangenes aangepak. Daarvoor het sy by die Ou Museum in Boomstraat in 'n pakkamertjie 'n kis vol voorwerpe van krygsgevangenes ondersoek [Fig. 1]. Dié studie was waarskynlik die grondslag vir die artikel "Die krygsgevangenes as 'n kultuurgroep", wat in die eerste uitgawe van die tydskrif Castalia in Oktober 1934 verskyn het. Dié tydskrif is juis gepubliseer vir die studente van die Departement Afrikaanse Kuns en Kultuur, Universiteit van Pretoria. 'n Vereniging met die naam "Castalides", onder voorsitterskap van Roodt, was ook aktief.

Die Staatsmuseum van die Zuid-Afrikaansche Republiek wat in 1892 tot stand gekom het, was die voorloper van die Transvaalmuseum, waaraan die nuwe naam in 1904 toegeken is. Die Transvaalmuseum het uit die "Ou Museum" in Boomstraat, Pretoria en sedert 1912 ook uit die "Nuwe Museum" in Paul Krugerstraat, Pretoria, bestaan.

4 K. Roodt-Coetzee, My herinneringe aan die voorgeskiedenis van die Nasionale Kultuurhistoriese en Opelugmuseum, Museum Memo 17(3), September 1989, p. 5. 

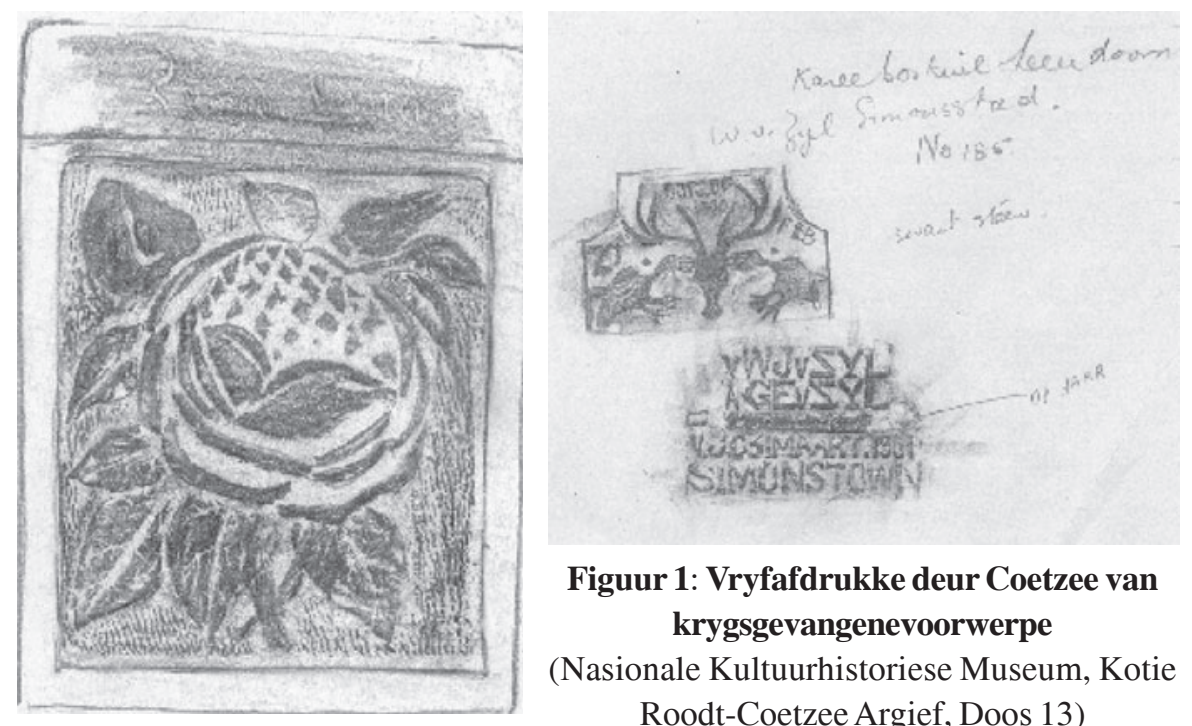

Figuur 1: Vryfafdrukke deur Coetzee van krygsgevangenevoorwerpe

(Nasionale Kultuurhistoriese Museum, Kotie Roodt-Coetzee Argief, Doos 13)

Roodt-Coetzee was in die breë spektrum van die kultuurgeskiedenis van die Afrikaner geïnteresseerd, soos blyk uit verskeie werkstukke en lesings wat in haar argief behoue gebly het. So het sy belanggestel in die verbrokkeling van die Boerekultuur, die ontwikkeling van die velskoen, Boerevolkskuns en die Afrikaanse vrou as skryfster voor en tydens die Groot Trek. ${ }^{5}$ Soos wat die tyd nader gekom het vir die Voortrekkereeufees in 1938, het Roodt-Coetzee 'n studie van die kleredrag van die Voortrekkers gemaak. Sy het verskeie artikels daaroor geskryf. In Die Volkstem van 3 November 1938 het "Kleredrag van die kind in die tyd van die Groot Trek" en in Die Transvaler van 6 September 1938, "Die regte drag vir die fees" verskyn. Sy het haar in die besonder in die studie van die Voortrekkerkappie verdiep en het met die oog hierop ook die Voortrekkermuseum in Pietermaritzburg besoek. Sy het verder by die Ou Museum in Pretoria tekeninge gemaak van patrone op kappies wat behoue gebly het. In die tekeninge verwys sy telkens na die Staatsmuseum en nie die Transvaalmuseum nie [Fig. 2]. In 'n artikel wat in 1938 in die Voortrekker-Gedenkboek van die Universiteit van Pretoria verskyn het, verskyn twee verwysings na die Staatsmuseum. ${ }^{6}$ Dit beteken dat sy op hierdie tydstip al bewus was van die vroeë

\footnotetext{
5 NKM, Kotie Roodt-Coetzee Argief, Doos 15, Lêer met studiestuk Sielkundige oorsake van die verbrokkeling van die Boerekultuur en Doos17, Lêer Werkstukke/Lesings.

$6 \quad$ K. Roodt-Coetzee, Die dekoratiewe in die Voortrekkerkleredrag, in I.D. Bosman, L.I. Coertze \& P.C. Coetzee, Voortrekker-Gedenkboek van die Universiteit van Pretoria (Universiteit van Pretoria, Pretoria, 1938), p. 121.
} 


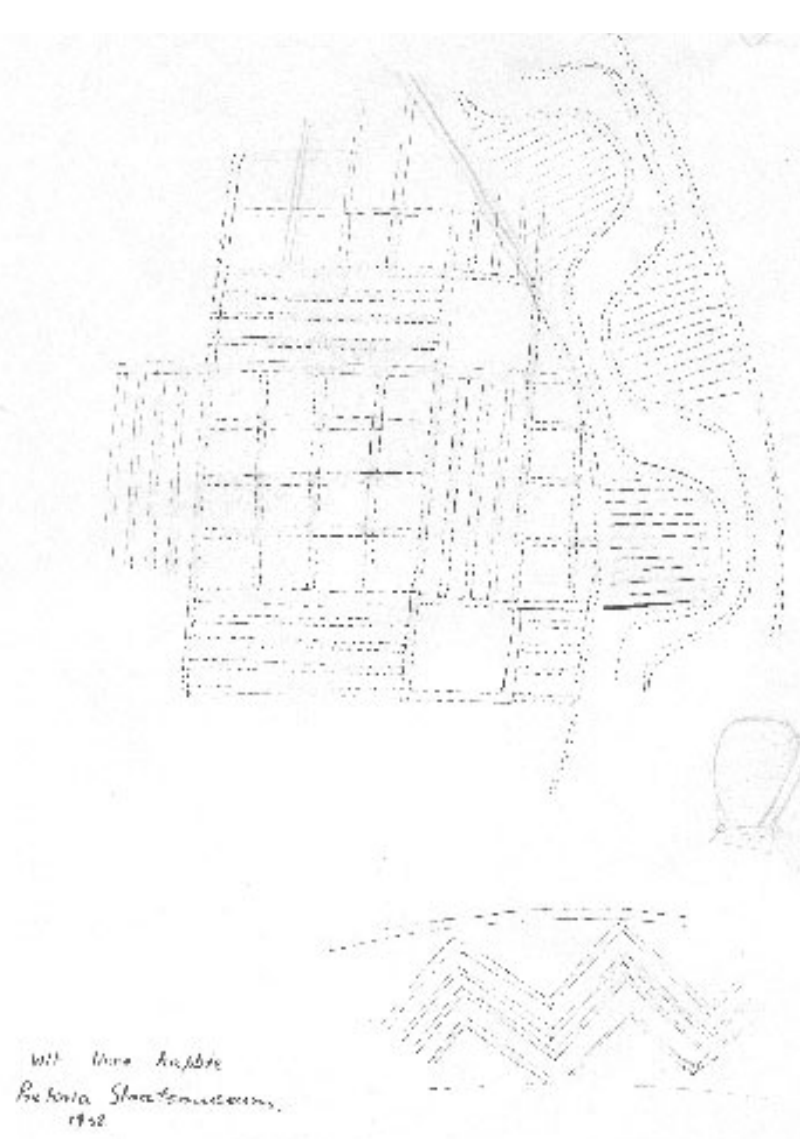

Figuur 2: Tekening van 'n kappie in die "Staatsmuseum” deur Coetzee, 1938 (Nasionale Kultuurhistoriese Museum, Kotie Roodt-Coetzee Argief, Doos 52)

geskiedenis van die Transvaalmuseum, wat ontstaan het uit die ou Staatsmuseum van die Zuid-Afrikaansche Republiek. Sy het haar toe reeds en vir jare daarna, vereenselwig met die ideale van die Staatsmuseum, wat volgens haar, die volle steun van president Paul Kruger geniet het. ${ }^{7}$

7 NKM, Argief, Media-vrystelling, Van Riebeeck-feeskomitee, K. Roodt-Coetzee, Die Kultuurhistoriese Museum, Boomstraat, Pretoria (NKM, Pretoria, 1952), p. 1. 
Sy was van mening dat die "Staatsmuseum" reeds aan die begin van 1938 'n baie mooi versameling Afrikanerkultuurvoorwerpe ${ }^{8}$ gehad het, selfs 'n groter verskeidenheid as dié van die Voortrekkermuseum in Pietermaritzburg. Sy was daarvan oortuig dat dié voorwerpe in 1938 uitgestal behoort te word en het die saak by die Kultuurraad van Pretoria aanhangig gemaak, ${ }^{9}$ maar so 'n uitstalling is nie gehou nie. 'n Verdere voorstel was dat die Transvaalmuseum se historiese afdeling na die Voortrekkermonument oorgeplaas behoort te word. ${ }^{10}$ Hierdie voorstel sou jare later vrugte afwerp toe sy 'n museum vir die Voortrekkermonument beplan en opgerig het.

Roodt-Coetzee was in daardie stadium ook bekend met die swak toestand van die historiese versameling in die Ou Museum, wat weggepak was in 'n pakkamer en nie vir die publiek toeganklik was nie. 'n Afvaardiging van die Kultuurraad, bestaande uit haar en P.J.S. de Klerk, het met die direkteur van die Transvaalmuseum, C.J. Swierstra, 'n onderhoud hieroor gevoer. Hy het soos volg gereageer:

Mnr Swierstra het gekla oor die gebrek aan ruimte en het aangeraai dat die Kultuurraad 'n versoek van die voltooiing van die museumgebou in Paul Krugerstraat, aan die regering moet rig, en dat die kultuurhistoriese materiaal in een of twee groot kamers uitgestal sal word. Op 'n vraag van my oor die klassifikasie het Mnr. Swierstra geantwoord dat dit onmoontlik was in die verlede om'n persoon te vind wat tegelyk 'n gekwalifiseerde geoloog, dierkundige en kultuurhistorikus is. Daar is ook nie geld om net 'n persoon vir die kultuurhistoriese afdeling alleen aan te stel nie. ${ }^{11}$

Die belangrikheid van kultuurhistoriese voorwerpe het in 1943 duidelik na vore gekom toe die Sentrale Volksmonumentekomitee bevind het dat die kunstenaars wat aan die historiese fries vir die Voortrekkermonument gewerk het, nie oor presiese kennis van die historiese feite beskik het nie. Roodt-Coetzee en ander lede van die historiese komitee is gevra om seker te maak dat die uitbeeldings histories juis is. Die gevolg hiervan was dat Roodt-Coetzee 'n uitstalling van Afrikaanse kultuurgoedere georganiseer het. Die uitstalling het van 22 tot 25 Mei 1943 in die Harmoniesaal plaasgevind, waar die kunstenaars gewerk het.

8 In die Transvaalmuseum was die afdeling aanvanklik as die historiese afdeling bekend. Dit was eers ná Roodt-Coetzee se aanstelling in 1953 op die personeel dat 'n kentering ingetree het en die naam kultuurhistoriese afdeling in gebruik gekom het.

9 NKM, Kotie Roodt-Coetzee Argief, Doos 1, Lêer A.T.K.V.-Museum, K. Roodt-Coetzee - D. Mostert, A.T.K.V.-Hoofbestuur, 1940-02-24.

10 NKM, Kotie Roodt-Coetzee Argief, Doos 1, Lêer A.T.K.V.-Museum, K. Roodt-Coetzee - D. Mostert, A.T.K.V. - Hoofbestuur, 1940-02-24.

11 NKM, Kotie Roodt-Coetzee Argief, Doos 1, Lêer A.T.K.V.-Museum, K. Roodt-Coetzee - D. Mostert, A.T.K.V.-Hoofbestuur, 1940-02-24. 
In 1943 het Roodt-Coetzee weer eens die swak toestand van die historiese afdeling by die Ou Museum by die Kultuurraad aanhangig gemaak. Sy het ook vir die stigting van 'n Africana-museum deur die Stadsraad van Pretoria gepleit. Die Kultuurraad het 'n komitee, bestaande uit Roodt-Coetzee, S.P.E. Boshoff, J.F.W. Grosskopf, J.H. Pierneef en H. Rode, aangestel om die toestand plaaslik te ondersoek en verslag te doen oor die herorganisasie van bestaande museums en die moontlike oprigting van 'n Africana-museum. Die volgende besware en sake is geopper rakende die Ou Museum: Die versamelings is verwaarloos en reeds vir geruime tyd ontoeganklik; die uitstalruimte is te klein; wisseluitstallings behoort aangebied te word om die gebrek aan ruimte te oorkom; beskrywings van voorwerpe op uitstalling moet juis wees; Museumkunde is heeltemal Engels-georiënteer; baie min word van die kurators verwag.

'n Besoek aan Swierstra het weer niks opgelewer nie. Hy het herhaal dat 'n beampte vir die historiese afdeling nie gou aangestel sou word nie en, indien dit sou geskied, dat dierkunde saam met kultuurgeskiedenis as akademiese vakke vereis sou word. ${ }^{12}$ Hierdie verslag het, waarskynlik as gevolg van die oorlogstoestand, geen positiewe resultate opgelewer nie.

Met die naderende inwyding van die Voortrekkermonument, het Roodt-Coetzee haar verder in haar studie van Voortrekkerklere verdiep. Sy is as 'n deskundige op dié gebied beskou. Volgens een koerantberig was sy in besit van honderde [sic] foto's van egte rokke, mansklere en dokumente en het sy ook die rokke ontwerp vir die drie dames wat die hoeksteen in 1938 gelê het. ${ }^{13}$ Verskeie koerantberigte en tydskrifartikels oor Voortrekkerklere het uit haar pen verskyn. ${ }^{14}$

Die geleentheid het hom nou voorgedoen om 'n uitstalling van kultuurhistoriese voorwerpe by die Voortrekkermonument aan te bied. Die Komitee ter Bevordering van die Historiese Museumwese was vir die beplanning van die uitstalling verantwoordelik. Die finale uitstalling is gekoördineer deur ' $n$ subkomitee van die Krugergenootskap, waarop die Transvaalmuseum ook verteenwoordig was. ${ }^{15}$ RoodtCoetzee was verantwoordelik vir die uitvoering van die uitstalling van voorwerpe van verskillende materiale (behalwe papier). Dit het volgens haar maande in beslag geneem. Oproepe is in die pers gemaak en voorwerpe ingesamel en vir uitstalling

12 K. Roodt-Coetzee, My herinneringe aan die voorgeskiedenis van die Nasionale Kultuurhistoriese en Opelugmuseum, p. 6.

13 Voortrekkerdrag meesal verkeerd voorgestel, Dagbreek en Sondagnuus, 1949-05-22, p. 7.

14 Meer egte Voortrekkerklere, Die Weekblad, 1949-06-10, p. 7; 'n Deskundige gesels oor Voortrekkerdrag, Die Vaderland, 1949-05-20, p. 13; Voortrekkertabberd vir fees in Desember, Die Transvaler, 1949-05-27, p. 3.

15 Raad van die Transvaalmuseum, notules, vergaderings 1949-05-13, 1949-08-05. 
gereed gemaak. Die skenkings is later by die versameling van die Transvaalmuseum geïntegreer. ${ }^{16}$

Intussen het Roodt-Coetzee ook 'n inligtingstuk oor die toestand van die $\mathrm{Ou}$ Museum voorgelê aan die Kommissie van Ondersoek na sekere staatsondersteunde inrigtings wat in 1948 deur die regering aangestel is. In die Kommissieverslag word die Ou Museum beskryf as ' $n$ gebou wat heeltemal ondoelmatig is: die vertrekke is donker en die ruimte vir die versameling te beperk. 'n Groot hoeveelheid materiaal van historiese belang is in die kelders gebêre. Hoewel die historiese stukke in die $\mathrm{Ou}$ Museum en die Krugerhuis ook van waarde was, het die onbevredigende wyse van uitstalling afbreuk aan die waarde gedoen. ${ }^{17}$ Die Kommissie het die aanstelling van 'n historikus op die personeel van die Transvaalmuseum aanbeveel. ${ }^{18}$

\section{Veranderinge in die geskiedenisafdeling by die Transvaalmuseum}

By die Transvaalmuseum self het geleidelik ook 'n verandering rakende die geskiedenis-afdeling ingetree. Dit kan toegeskryf word aan die nuwe direkteur, F.V. FitzSimons, se bereidwilligheid om 'n tydelike deeltydse personeellid aan te stel om die historiese voorwerpe te indekseer. Dit het tot die ontdekking van 'n groot hoeveelheid waardevolle historiese materiaal gelei. Meer nog, Roodt-Coetzee het langer as twee jaar vrywillig by die Museum gewerk om die uitstalling vir die Van Riebeeckfees in 1952 te beplan en op te stel. Sy was die voorsitter van die uitstalkomitee en het toegesien dat die publiek vir die eerste keer'n groot verskeidenheid voorwerpe kon besigtig wat jare lank in die Museum se pakkamers gelê het [Fig. 3]. ${ }^{19}$

Vanweë die beperkte uitstalruimte is baie voorwerpe in die Museum se pakkamers nie uitgestal nie. Die toestand is soos volg beskryf:

In the cellar of the museum are hundreds of amazing and mysterious articles for which there is no room on the exhibition.

A huge crossbow... lies among hundreds of old guns and rifles from all over the world. These include old Indian rifles ... elephant guns... a home-made

\footnotetext{
16 K. Roodt-Coetzee, My herinneringe aan die voorgeskiedenis van die Nasionale Kultuurhistoriese en Opelugmuseum, p. 6.

17 NKM, Argief, Verslag van die Kommissie van Ondersoek na sekere staatsondersteunde inrigtings (Du Toit-kommissie), 1950, pp. 34-35.

18 NKM, Argief, Verslag van die Kommissie van Ondersoek na sekere staatsondersteunde inrigtings (Du Toit-kommissie), 1950, p. 172.

19 Die Volksgenoot, 1952-03-27; Die Transvaler, 1952-03-14.
} 


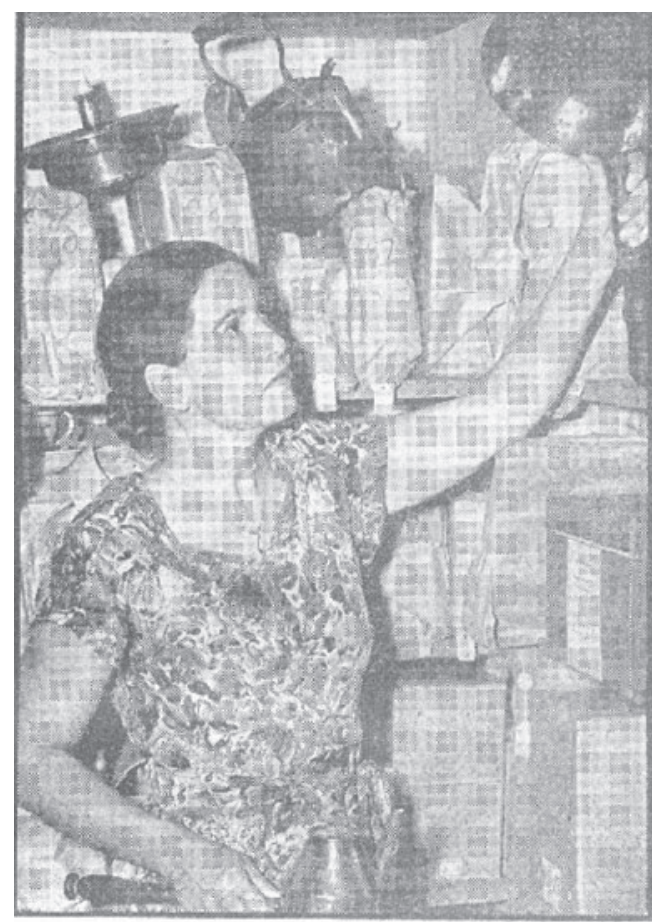

Figuur 3: Coetzee in 'n pakkamer in die Ou Museum, 1952

(Die Transvaler, 1952-01-10)

cross bow and a variety of other guns which together must constitute an almost unique collection.

An air of mystery hangs over a cycle standing covered with dust in one corner, amid elephant skulls, skeletons and machines for making bullets. ${ }^{20}$

Roodt-Coetzee het haar in die besonder vir die insamel van fondse vir die maak van 'n aantal uitstalkaste beywer, en volgens haar was elke donasie om 'n glaskas te koop “... 'n donasie wat vir eeue in die toekoms gaan bly staan en wat daartoe gaan bydra om die publiek die voordeel van 'n kulturele erfenis te gee waartoe dit geregtig is."21 'n Bedrag van $£ 7000$ is binne twee maande ingesamel en die bou van die kaste is deur

20 Pretoria News, 1952-01-30.

${ }^{21}$ NKM, Argief, Media-vrystelling, Van Riebeeck-feeskomitee, K. Roodt-Coetzee, Die Kultuurhistoriese Museum, Boomstraat, Pretoria, p. 4. 
die Suid-Afrikaanse Spoorweë en Hawens en die Stadsraad van Pretoria onderneem. ${ }^{22}$ Hierdie kaste en 'n bykomende bedrag geld vir die nodige wysigings is deur die Van Riebeeckfeeskomitee aan die Transvaalmuseum geskenk..$^{23}$

Hoewel die Museum reeds 'n versameling historiese voorwerpe gehad het, was daar veral uit die tydperk 1650 tot 1750 aan die Kaap feitlik geen voorbeelde nie. ' $n$ Beroep is op die publiek gedoen om voorwerpe uit hierdie tydperk vir die uitstalling aan die Museum te leen, met die versekering dat daar voldoende sekuriteit sou wees en dat die naam van die lener by die voorwerpe geplaas sou word. ${ }^{24}$ Besoekers aan die uitstalling kon ook vir die eerste keer seldsame oudhede te siene kry [Fig. 4].

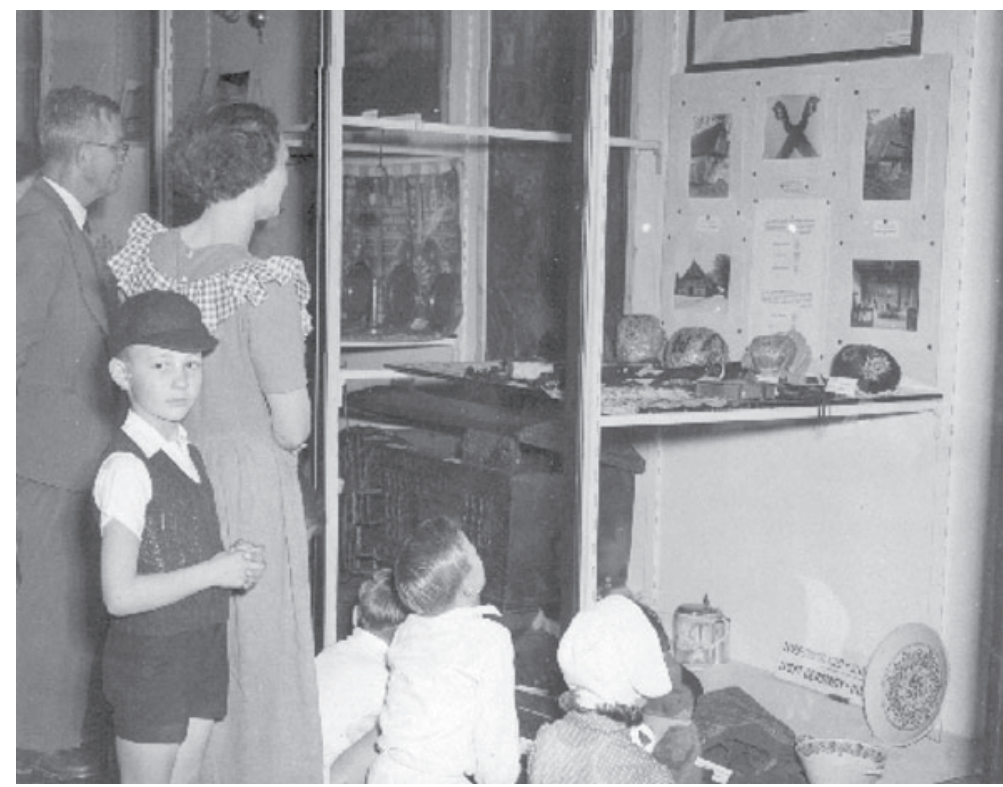

Figuur 4: Besoekers by oudhede (VOC-periode). Die voorwerpe is spesiaal uit Wes-Duitsland vir die Van Riebeeckfeesuitstalling per lugpos na Pretoria gestuur

(Nasionale Kultuurhistoriese Museum, Kotie Roodt-Coetzee Argief, Doos 41)

2 Transvaalmuseum, Jaarverslag, 1952-1953, p. 8.

23 Transvaalmuseum, Jaarverslag, 1953-1954, p. 10.

${ }^{24}$ Die Vaderland, 1952-02-02; Pretoria News, 1951-12-06. 
Die gebrek aan uitstalruimte, die toestand van die museumpakkamers en leemtes in die versameling is deur Roodt-Coetzee tydens die Van Riebeeckfees onder die loep geneem. Sy het ook nie gehuiwer nie om met die opening van die uitstalling te wys op die uiters swak toestand van die museumgebou, veral as dit gereën het en houers gebruik moes word om lekkende water op te vang. Sy het 'n nuwe museumgebou vir Pretoria, wat 'n vergrote museum moes huisves, in die vooruitsig gestel. ${ }^{25}$

Die Transvaler van 14 Maart 1952 het die uitstalling beskryf as die grootste geskiedkundige uitstalling wat nog in Transvaal gesien is. ${ }^{26}$ Oorsese besoekers was van mening dat die uitstalling op gelyke standaard aan dié in Europa was. ${ }^{27}$ Volgens dr R. van Luttervelt, assistent-direkteur van die Staatsmuseum (Rijksmuseum?) in Amsterdam, Nederland, was die hoogtepunt van die uitstalling die Voortrekkermeubels en die Kaapse silwer. Die Voortrekkervoorwerpe het 'n skoonheid van lyn en proporsie wat besonder aantreklik is, aldus Van Luttervelt. ${ }^{28}$

Vir die uitmuntende diens wat sy op die gebied van die Geskiedenis aan die Transvaalmuseum gelewer het, is geassosieerde lidmaatskap van die Museum in 1952 aan Roodt-Coetzee toegeken.

\section{Kotie Roodt-Coetzee op die personeel van die Transvaalmuseum}

Op 1 September 1953 is Roodt-Coetzee as vakkundige beampte vir die geskiedenisversameling by die Transvaalmuseum aangestel [Fig. 5]. Dit was die begin van 'n verbintenis van 25 jaar tot met haar aftrede in 1978.

Die versameling is geleidelik tot een van die omvangrykste kultuurhistoriese versamelings in Suid-Afrika uitgebou. Sy het onmiddellik begin 'n ondersoek na die stand van sake in die Ou Museum en die Krugerhuis geloods en het ook 'n memorandum oor die beoogde museum by die Voortrekkermonument opgestel. ${ }^{29}$ Haar tyd is in 'n groot mate deur die ontwikkeling van die drié museums in beslag geneem. Al die geykte museumfunksies het aandag gekry: die uitbou van die versamelings, beplanning en oprigting van nuwe uitstallings en uitstaltegnieke. Die dokumentasie van voorwerpe is nou vir die eerste keer sedert die stigting van die Staatsmuseum in 1892 deur 'n opgeleide vakkundige behartig. Die gespesialiseerde konservering van kultuurhistoriese voorwerpe het voorkeur geniet. Die opleiding van vakkundiges is as 'n onontbeerlike vereiste vir museumwerk beskou. Trouens, sy het daarin geslaag

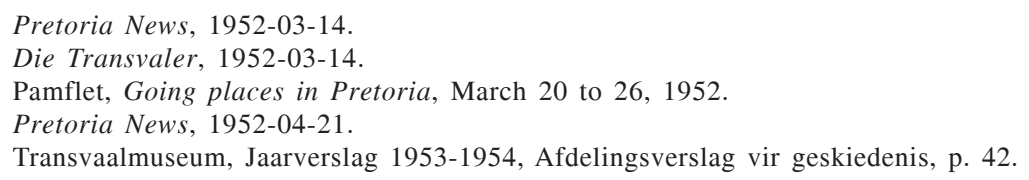




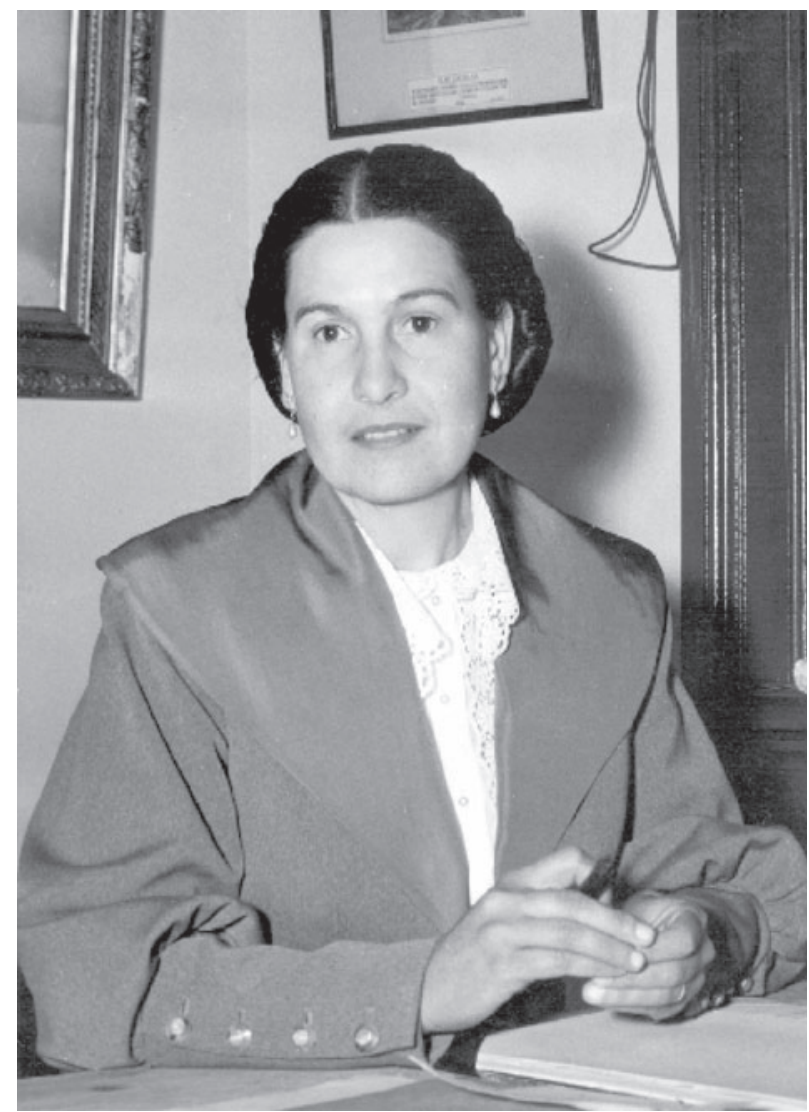

Figuur 5: Coetzee pas na haar aanstelling as vakkundige by the Transvaalmuseum in 1953

(Nasionale Kultuurhistoriese Museum, Kotie Roodt-Coetzee Argief, Doos 37)

om die meeste moderne versamelingsbestuurpraktyke wat eers in die sestigerjare van die twintigste eeu vorm begin aanneem het, reeds tien jaar vroeër toe te pas.

Van 1953 af het voortdurende dinamiese verandering in die geskiedenisafdeling van die Transvaalmuseum plaasgevind. Die status van die geskiedenis- en later die kultuurgeskiedenisafdeling het verander. Waar dit eers afgeskeep en onversorg was, het dit nou 'n betekenisvolle deel van die Museum geword. In die vormingsjare van die afdeling het Roodt-Coetzee reeds die grondslag vir die totstandkoming van 'n nuwe kultuurhistoriese museum gelê. Die werk was nou vir die eerste keer in die hande van 'n opgeleide vakkundige. Sy het haar veral op twee terreine onderskei: 


\section{Nuwe uitstallings}

Die historiese uitstallings by die Ou Museum het jare lank dieselfde gebly. Na haar aanstelling het sy onmiddellik die uitstallings begin verander. Die hout bokante van die uitstalkaste is deur glas vervang, wat beteken het dat dit baie ligter was en nuwe lessenaartipekaste wat deur die Departement van Handel geskenk is, het die ruimteprobleem effens verlig.

Roodt-Coetzee het die standpunt gehuldig dat voorwerpe op uitstalling gewissel of verander moes word om so 'n wye verskeidenheid as wat moontlik is, uit te stal. Besoekers aan die Museum kon dus tydelike uitstallings, wat mekaar redelik vinnig afgewissel het, besigtig. Die uitstallings het dikwels met nuuswaardige gebeurlikhede verband gehou. So byvoorbeeld het 'n uitstalling oor die lewe van president T.F. Burgers saamgeval met die onthulling van die Burgers-standbeeld in Pretoria in Oktober 1953. Die geskiedenis van die Huis van Oranje is vir die besoek van prins Bernhard van Nederland aan Suid-Afrika in Oktober 1954 aangebied. 'n Spesiale uitstalling van Krugervoorwerpe het die verskuiwing van die Krugerstandbeeld na Kerkplein in Oktober 1954 ondersteun.

Die gebrek aan ruimte in die Ou Museum het tot gevolg gehad dat die volgende groot uitstalling (die eeufeesviering van Pretoria in 1955) wat Roodt-Coetzee se aandag geverg het, nie daar gehou kon word nie, maar in die Hollandiasaal in Proesstraat, Pretoria. Roodt-Coetzee het byna sewe maande aan die beplanning en opstel van die Pretoria-uitstalling gewerk. Die uitstalling is op 25 November 1955 deur die burgemeester van Pretoria geopen en het baie lof ingeoes. Die geskiedenis van die stad is deur vyf dioramas uitgebeeld, waarin Pretoria soos die stad in 1855 daar uitgesien het, met die omstandighede 'n eeu later vergelyk is. Twee periodekamers het die leefwyse in 1855 en 1895 uitgebeeld. Daar was ook 'n uitspantoneel.

Dié nuwe uitstalwyse was 'n uitvloeisel van Roodt-Coetzee se mening dat voorwerpe in 'n moderne kultuurmuseum in die konteks van die mens se lewens- en gebruiksverband uitgestal moes word. Die uitstalkaste wat jare lank in museums gebruik is, was regopstaande reghoekige, vierkantige of langwerpige kaste of vrystaande lessenaartipekaste. Uitstalskerms en swaairame is ook soms gebruik. Hoewel Roodt-Coetzee nie gehuiwer het om dergelike kaste te gebruik nie (in die $\mathrm{Ou}$ Museum was daar totdat die gebou ontruim is, langwerpige glaskaste met Chinese porselein wat sy ingerig het) het sy na nuwe uitstaltegnieke begin soek.

Besoekers aan die natuurhistoriese museum kon na diere in hulle natuurlike omgewing kyk - die sogenaamde habitat-uitstalling. Roodt-Coetzee, wat met die Transvaalmuseum vertroud was, het waarskynlik gereken dat sy dieselfde kon doen om die leefstyl van mense uit te beeld. Kultuurhistoriese voorwerpe wat in hulle 
natuurlike konteks uitgestal word, sou ook vir die besoekers 'n geloofwaardiger beeld van die leefstyl van die verlede as een voorwerp in isolasie, of 'n verskeidenheid voorwerpe in 'n kas gee. Sy is waarskynlik ook beïnvloed deur die afbeeldings van kamers in volksmuseums wat sy in oorsese tydskrifte gesien het. In haar argief is byvoorbeeld ' $n$ tydskrif met afbeeldings van die Walliese volksmuseum in St. Fagankasteel in Cardiff [Fig. 6]. ${ }^{30}$

In die biblioteek van die Transvaalmuseum kon sy 'n tydskrif soos The Museums Journal (die mondstuk van die Britse museumvereniging) raadpleeg. Dié tydskrif het voortdurend foto's van vertrekke in volks- en opelugmuseums en ander museumuitstallings gepubliseer. So is afbeeldings geplaas van 'n kothuis-interieur in die Gothen-

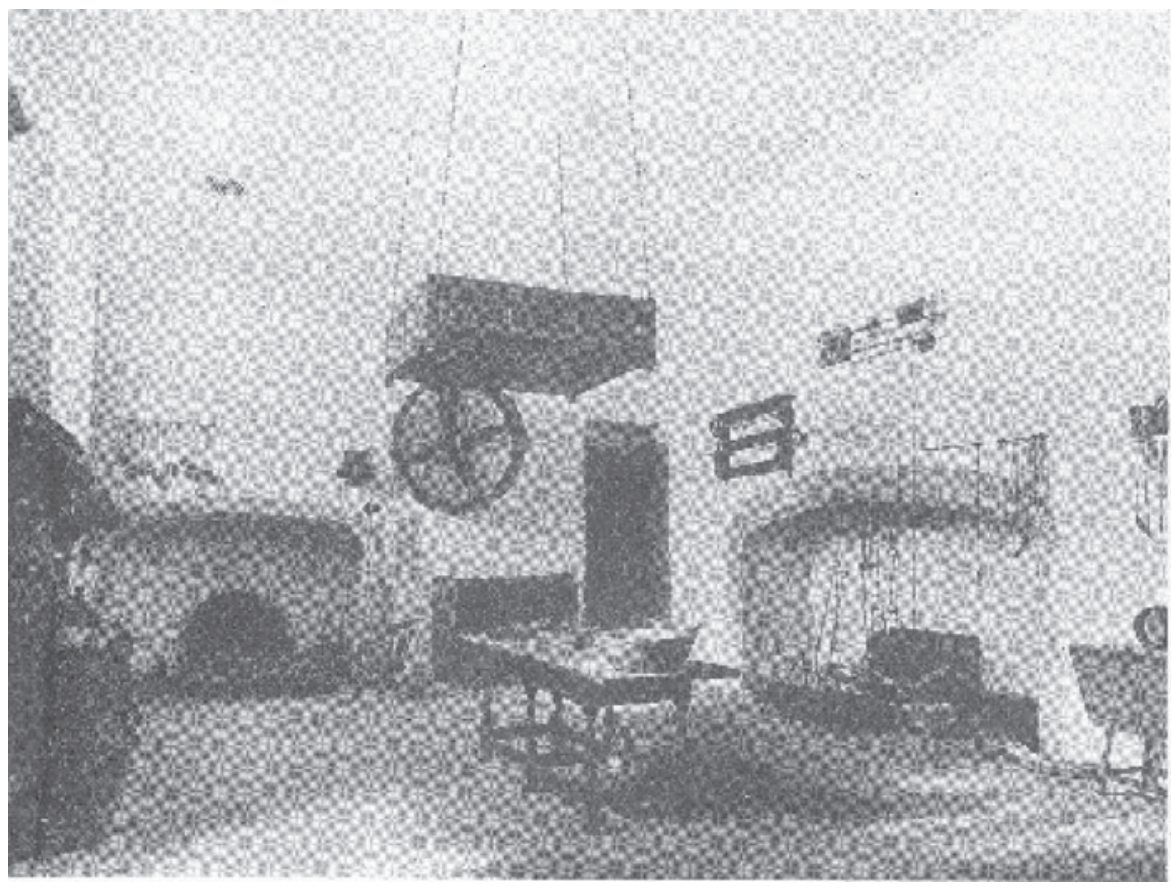

Figuur 6: Die kombuis in St. Faganskasteel, Walliese volksmuseum, Cardiff, 1949

(Uit: I.C. Peate, The Folk Museum, Journal of the Royal Society of Arts XCVII (4803), 1949-09-09, p. 803)

30 I.C. Peate, The Folk Museum, Journal of the Royal Society of Arts XCVII (4803), 1949-0909, pp. 800-803. 
burg Museum wat deel van die gewone uitstalsaal is, ${ }^{31}$ 'n vertrek in 'n plaashuis in die Skansen-opelugmuseum ${ }^{32}$ en 'n Rokokokamer in die Nordenfjeldske museum, Trondheim. ${ }^{33}$ Sy het self gesê dat `n foto van `n voorstelling van `n Australiese pioniersfamilie vir haar die sleutel tot die nuwe uitstalwyse was. ${ }^{34}$

Roodt-Coetzee beskryf die gebruik van kamers binne-in museums in plaas van die tradisionele uitstalkaste as uniek. Sy het ook die periodekamer-tegniek in die uitstallings in die Voortrekkermonumentmuseum gebruik, waar sy 'n kombuis, slaapkamer en voorhuis gerekonstrueer het. Op hierdie wyse is die lewenstyl van die verlede vir die besoekers op 'n lewendige, aanskoulike en verstaanbare wyse voorgestel.

Die Pretoria-uitstalling is deur ' $n$ verskeidenheid uitstallings gevolg. By die Transvaalmuseum (ook in die omgangstaal bekend as die Nuwe Museum) het uiteenlopende voorwerpe - uit die Smutsversameling, papiergeld en "good-fors" uit die Republikeinse dae, Steentydperkwerktuie, vroeë Chinese porselein en polisiekentekens -vir verskeidenheid gesorg. By die Ou Museum is 'n uitstalling "Van grot tot kampong", gevolg deur 'n uitstalling oor die Britse nedersetters in Suid-Afrika en een oor die "Bantoe as kunstenaar" aangebied. Uitstallings oor Afrikaen Peru-kulture is ook gehou en met die Uniefees in 1960 is 'n uitstalling van die Eerste Ministers van Suid-Afrika aangebied. Toe die Unie 'n Republiek geword het, is 'n spesiale uitstalling oor die wêreldmening en die Zuid-Afrikaansche Republiek gehou. Baie voorwerpe wat gedurende die Anglo-Boereoorlog as eerbetoon aan die Boere gegee is, is vir die eerste keer vertoon.

Op 6 November 1962 is Roodt-Coetzee se geslaagdste uitstalling geopen. In 'n nuwe uitstalling van Kaapse silwer en meubels, is die voorwerpe chronologies gerangskik. Vir die eerste keer kon Westerse kultuurstyle, soos verteenwoordig in Suid-Afrikaanse stukke, besigtig word. Die doel van die uitstalling was om voorwerpe as dokumente van die verlede wetenskaplik te verklaar en om waardering vir die kultuurerfenis van die blanke [sic] te wek. Die uitstalling het uit huisraad bestaan voorwerpe soos 'n hoekkas, stoel, bank, tafeltjie, voetstofie en klaptafel -aangevul met eietydse breekgoed en kombuisgereedskap, soos 'n skuimspaan, pot en trekketel. Besonderse stukke Kaapse silwer was op uitstalling: 'n borsplaat van A. von Wielligh, 'n Kaapse regimentsoffisier uit 1788, 'n verskeidenheid lepels, soos 'n ponslepel, lemoenlepeltjie, dessertlepels, soplepels, bredielepels, mosterdlepeltjie, murglepel en

\footnotetext{
The Museums Journal 3(2), August 1903, Plate III.

The Museums Journal 3(4), October 1903, Plate XXVIII.

The Museums Journal 3(2), Plate XV.

K. Roodt-Coetzee, My herinneringe aan die voorgeskiedenis van die Nasionale Kultuurhistoriese en Opelugmuseum, p. 7.
} 
soutlepel, asook 'n kaneelstrooier, pleisterdosie, botterverkoeler uit 1830, snuifdoos en eierstander. Gotiese en Renaissance elemente in die voorwerpe op uitstalling is aangetoon; die Barok-, Regence- en Rokokostyle en Klassisisme is in huisraad en silwer verteenwoordig, terwyl meubels van die Britse Setlaars eweneens uitgestal is. Suid-Afrikaanse meubels uit die negentiende eeu het meubels van die Groot Trek en die Transgariep, meubels uit Kaapland ná 1820 en ingevoerde meubels ingesluit. Die uitstalling het nie net van Roodt-Coetzee se kundigheid getuig nie, maar ook haar besondere vermoë om voorwerpe wat sy vir die versameling nodig geag het, te identifiseer en in te samel. ${ }^{35}$

\section{Nuwe versamelings}

Die Transvaalmuseum het reeds in 1953 oor een van die verteenwoordigendste en uiteenlopendste geskiedenisversamelings in Suid-Afrika beskik, maar Roodt-Coetzee het baie leemtes geïdentifiseer, byvoorbeeld 'n gebrek aan Kaaps-Hollandse meubels. Min voorwerpe uit die tydperk van die Vereenigde Oostindische Compagnie (VOC) was in die Museum aanwesig.

Die voorwerpe wat ingesamel moes word, moes, volgens Roodt-Coetzee, 'n "dokument" wees. Juis hierin lê waarskynlik haar grootste bydrae tot die SuidAfrikaanse museumwese en kultuurgeskiedenis: voorwerpe was nou nie meer, soos hulle gewoonlik in die verlede genoem is, 'n eksemplaar (“specimen"), 'n oorblyfsel ("relic") of 'n aandenking ("curio") nie, of self nie net 'n aanwins ("acquisition/ accession") of 'n rariteit ("curiosity") nie. Hoewel sy self die terme "Africana" en antikwiteit ("antique") gebruik het, het hulle nie die presiese betekenis van die kultuurhistoriese voorwerp weergegee nie. Vir haar was die kultuurhistoriese voorwerp 'n dokument, waaruit die lewenstyl van die maker of gebruiker afgelei kon word. Elke voorwerp was vir Roodt-Coetzee

...'n dokument van die verlede, dis 'n getuienis oor hoe hulle in die verlede geleef, gewerk en gedink het, en waarna hulle gestreef het. Hulle meubels en naaldwerk, hulle klere en glas en aardewerk, hulle silwer en velwerk, al hierdie dinge wat deur ons eie mense op ons eie bodem gemaak is, dit is die dokumente wat ons beskou, bekyk, bestudeer en ons lei daaruit af wat die aard en karakter en strewing van ons mense was. Ons leer hulle daaruit ken en ook onsself. ${ }^{36}$

35 K. Roodt-Coetzee, Kaapse silwer en meubels uitstalling, 1962.

36 NKM, Argief, Stelsel 1 No. 18 TM1/62, radiopraatjie, K. Roodt-Coetzee, Uitstalling van Kaapse silwer en meubels, November 1962. 
Kriteria wat in die verlede gegeld het, soos die gewone assosiasies tussen voorwerp en persoon (meestal 'n baie belangrike persoon) of voorwerp en 'n gebeurtenis, was dus nie vir Roodt-Coetzee die belangrikste aspek waaraan die voorwerp moes voldoen nie. 'n Voorwerp moes voorts nie noodwendig uniek, mooi of uitsonderlik wees nie.

Met ' $n$ duidelike begrip van watter voorwerpe versamel moes word, het RoodtCoetzee 'n "soek- en speurtog begin om die vereiste kultuurdokumente te vind." ${ }^{37}$ Sy het daarin geslaag om groot versamelings Kaapse silwer, meubels, koper en keramiek, asook 'n kostuumversameling op te bou. Die publiek is oor die radio en in die pers versoek om voorwerpe te skenk wat die Museum nodig gehad het. Een van die grootste redes vir Roodt-Coetzee se sukses was die feit dat sy mense persoonlik ontmoet het. Haar oortuiging dat sy nie vir eie gewin gewerk het nie, maar vir 'n saak, het telkens die deurslag gegee. Baie van die briewe wat sy geskryf het, was nie formele sakebriewe nie, maar getuig van haar warme belangstelling in die persoon self, sy omstandighede en familie. Sy het ' $n$ spesiale poging aangewend om versamelaars, kundiges, kurators, antiekhandelaars en selfs staatsamptenare te leer ken, in die verwagting dat hulle haar werk kon bevorder. Sy was 'n gewilde spreker en het talle vroue- en kultuurverenigings en skoliere en studente toegespreek en by feesgeleenthede opgetree. Hoewel daar vantevore dan en wan koerantberigte oor skenkings of interessante voorwerpe verskyn het, het Roodt-Coetzee se geesdriftige reklame begin vrugte afwerp en het die kultuurhistoriese versameling aanhoudend gegroei.

Die voorwerpe moes by die wetenskaplike studie van kultuurgeskiedenis gebruik word. Roodt-Coetzee was dus gesteld daarop dat die voorwerpe outentiek moes wees en dat alle moontlike inligting verkry, noukeurig ondersoek en gedokumenteer moes word. Sy het elke moontlike leidraad gevolg om voorwerpe en inligting te bekom. Sy het briewe aan die skenkers geskrywe, selfs al was dit jare na die skenking; nadat sy 'n relevante koerantberig gelees het, het sy met daardie persoon in aanraking probeer kom, en selfs die Suid-Afrikaanse Polisie gevra om 'n persoon op te spoor wat dalk 'n voorwerp aan die Museum kon skenk.

Roodt-Coetzee het reeds met haar eerste kennismaking met die Transvaalmuseum in die dertigerjare besin oor die "noodsaaklikheid van stoflike voorwerpe by die teoretiese studie van kultuurgeskiedenis" en sy het haarself afgevra hoe sodoende voorwerpe beskryf moes word. ${ }^{38}$ Aan die direkteur van die Transvaalmuseum, Swierstra, het sy reeds in 1939 vrae oor die klassifikasie van voorwerpe gestel. Na

\footnotetext{
37 NKM, Kotie Roodt-Coetzee Argief, Doos 1, lêer Persoonlik 2, Kotie Roodt-Coetzee en die Kultuurhistoriese Museumwese in Suid-Afrika, p. 9.

38 K. Roodt-Coetzee, My herinneringe aan die voorgeskiedenis van die Nasionale Kultuurhistoriese en Opelugmuseum, p. 5.
} 
haar aanstelling het sy 'n algehele verandering aan die dokumentasie van kultuurhistoriese voorwerpe aangebring. Volgens haar was die doel van klassifikasie om inligting oor die voorwerp vas te stel en te dokumenteer. Hierdie inligting het die land van herkoms van die voorwerp, datum van vervaardiging, materiaal wat gebruik is, konstruksie- en vervaardigingstegnieke, die toestand van die voorwerp, enige spesifieke kenmerke of afwykings en die ouderdom van die voorwerp ingesluit. Die geskiedenis van die voorwerp en dié van die skenker en familie was ook belangrik. Die plek, datum en manier van versameling moes gedokumenteer word en die voorwerp moes duidelik geïdentifiseer en benoem word. Laasgenoemde aspek het uiteindelik tot 'n stelsel van trefwoorde in die katalogus gelei ${ }^{39}$ en die samestelling van 'n kaartkatalogus wat voorheen in die geskiedenis-afdeling ontbreek het. Volgens RoodtCoetzee het katalogisering die volgende behels: die aanwin van elke voorwerp in 'n katalogus volgens die klassifikasie, met 'n unieke aanwinsnommer, en die maak van 'n stamkaart met die basiese gegewens oor die voorwerp en verskeie newe-inskrywings.

Met die ontwerp van 'n museologiese kaartkatalogus het Roodt-Coetzee die insette van haar man, prof. P.C. Coetzee, 'n biblioteekkundige en hoof van die Departement Biblioteekkunde aan die Universiteit van Pretoria, nuttig gebruik. Geen lys van erkende trefwoorde ${ }^{40}$ vir kultuurhistoriese voorwerpe was in Afrikaans beskikbaar nie en die talle veranderinge aan name van voorwerpe in die katalogus getuig van die gesukkel om die presiese woord te identifiseer.

Roodt-Coetzee het klassifisering ook in die gewone sin van die woord gebruik, naamlik die ordening van soortgelyke voorwerpe bymekaar en afsonderlik van ander voorwerpe wat van hulle verskil. Nog voor haar aanstelling by die Transvaalmuseum het sy begin met die sortering van historiese voorwerpe, terwyl sy besig was om hulle vir die Van Riebeeck-uitstalling te keur. Van 1953 af het sy begin om voorwerpe soos kostuums, foto's, uniforms, dokumente, Bybels, godsdienstige boeke en ander te sorteer. Die antropologiese en argeologiese voorwerpe en dié wat met Paul Kruger geassosieer is, is gesorteer en afsonderlik verpak.

Die samestelling van 'n kaartkatalogus met beskikbare inligting het die voorwerpe toegankliker gemaak. Onderwerp-, skenker-, persoonlike en plekkaarte is getik om die gegewens op die stamkaart aan te vul. Die agterstallige werk (d.w.s. die ontsluiting van die ou versameling wat reeds in die Museum was) het dikwels nie na wense gevorder nie, omdat soveel nuwe aanwinste aangekom het wat eers afgehandel moes word. Die

\footnotetext{
39 Met "katalogus" word die aanwinsregister bedoel.

40 Die eerste Afrikaanse trefwoordelys vir kultuurhistoriese voorwerpe is deur die Nasionale Kultuurhistoriese en Opelugmuseum gepubliseer, nl. L. Slabbert, Trefwoorde vir kultuurhistoriese voorwerpe (Pretoria, 1973).
} 
werk was ook tydrowend, aangesien daar van elke voorwerp 'n skets in potlood [Fig. 7] op die kaart gemaak moes word. Nietemin is byvoorbeeld tussen 1957 en 1958 'n bykomende 1,545 agterstallige kaarte getik.

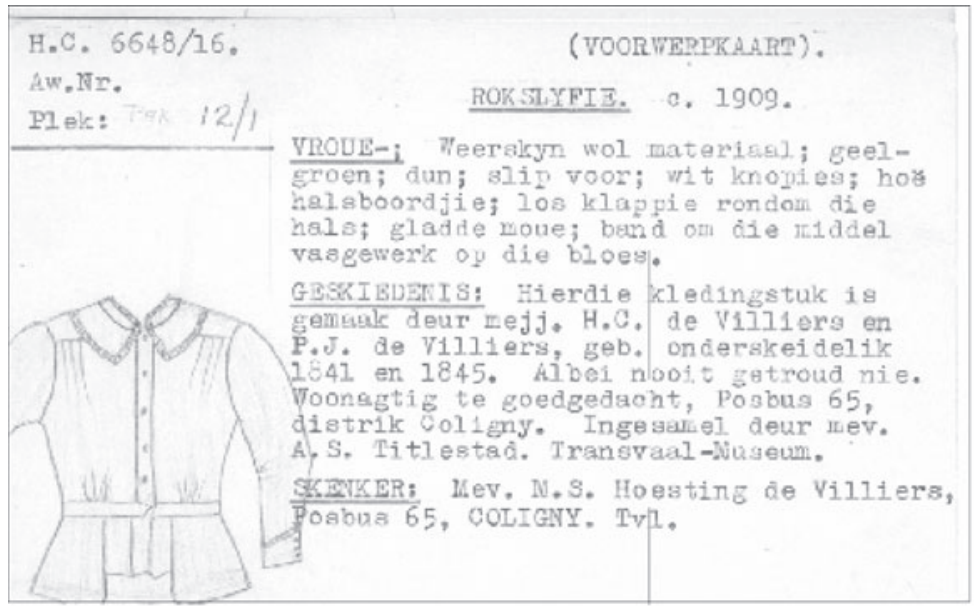

Figuur 7: 'n Potloodskets van 'n voorwerp op 'n kataloguskaart (Nasionale Kultuurhistoriese Museum, Dokumentasiesentrum)

Een van die belangrikste faktore waaraan Roodt-Coetzee aandag gegee het, was die bewaring van die versameling. Sy het byvoorbeeld self die klere heelgemaak wat by die Voortrekkermonument uitgestal sou word. Sy het daarop aangedring dat ' $n$ restourateur onontbeerlik was, wat in 1957 tot die aanstelling van so 'n persoon gelei het. Hy het onmiddellik met die restourasie van meubels, ou wapens, kombuisgebruiksvoorwerpe en plaasimplemente begin. Verder was hy vir algemene skrynwerk verantwoordelik en moes replikas maak. 'n Assistent is aangestel, wat onder Roodt-Coetzee se toesig die restourasie van tekstiele onderneem het en replikas van kleredrag gemaak het.

Restourasiewerk wat nie in die Museum onderneem kon word nie, is uitgekontrakteer, soos manuskripte en Bybels wat deur die bindery van die Staatsargief herstel is. Kunswerke is deur J. van Tilburg gerestoureer. Roodt-Coetzee het al die werk beplan en tot in die fynste besonderhede, veral met betrekking tot die materiaal en korrekte ou tegnieke, met die restourateur bespreek. Sy het ook voortdurend toesig oor die restourasiewerk gehou.

Roodt-Coetzee was bewus daarvan dat konservering 'n gespesialiseerde vakgebied was en het voortdurend op hoogte probeer bly met die nuutste literatuur en 
tegnieke. Met haar eerste studiereis oorsee (Maart tot September 1959) het sy by verskeie gevestigde konserveringslaboratoriums aangedoen om inligting in te samel. Van 23 Junie tot 6 Julie 1963 het sy 'n opleidingskursus by die navorsingslaboratorium van die Britse Museum in Londen bygewoon. Dié kundigheid kon sy onmiddellik in die Museum aanwend. Sy het die personeel self opgelei, maar volgens 'n oud-personeellid was die liefde wat sy vir eie kultuurgoedere by hulle gekweek het, veel belangriker. ${ }^{41}$

Aangesien sy oorweldig is met navrae van plaaslike museums en munispaliteite oor die organisering van 'n kultuurhistoriese museum, uitstallings en bewaring, het dit later onmoontlik geword om persoonlike aandag aan elke navraag te gee. Die gebrek aan kundigheid het haar laat besef dat museumkundige opleiding uiters noodsaaklik was. Sy het dus 'n kursus in museumtegnieke by die Ou Museum gereël wat bestaan het uit negentien lesings, waarvan sy self nege aangebied het. Die ander lesings is deur kundiges van buite aangebied. 'n Besonder wye veld is gedek, van die geskiedenis van die museumwese, die keuring van voorwerpe vir die kultuurhistoriese museum tot museumsekuriteit en die identifikasie van SuidAfrikaanse houtsoorte. Die kursus was besonder suksesvol en sy het groot lof van die kursusgangers ingeoes.

\section{'n Nuwe museum}

Voor haar aanstelling by die Transvaalmuseum in 1953 het Roodt-Coetzee reeds met die ongemaklike situasie kennis gemaak - in 'n museum wat op natuurwetenskaplike navorsing ingestel was, was ' $n$ historiese of kultuurhistoriese afdeling nie 'n prioriteit nie. Ná haar aanstelling het dit duidelik geword dat 'n tradisionele natuurhistoriese opset nie met gemak die vereistes van die kultuurgeskiedenis kon hanteer nie. Sy het haar beywer vir die totstandkoming van 'n sterk kultuurhistoriese afdeling in die Museum, soos blyk uit die uitstallings wat sy beplan en uitgevoer het, en veral die voorwerpe wat sy begin insamel het. Op bestuursvlak was die eerste aanduiding dat veranderinge aan die kom was, die instelling deur die Raad van die Transvaalmuseum van 'n spesiale Historiese Subkomitee in Junie 1955.

Die totstandkoming van die Nasionale Kultuurhistoriese en Opelugmuseum in 1964 is voorafgegaan deur ' $n$ lang proses waarin Roodt-Coetzee binne en buite die Museum persone en instansies oortuig het dat afskeiding die enigste oplossing vir die probleem is. Sy het byvoorbeeld in 1958 'n memorandum ten behoewe van die

${ }_{41}$ O.J.O. Ferreira, Kotie-Roodt-Coetzee, kulturele mentor en voog van vele, Museum Memo 22(1), p. 3. 
Historiese Genootskap van Suid-Afrika voorberei, waarin sy die feit beklemtoon het dat die natuurhistoriese en die kultuurhistoriese rigtings in 'n museum uitlopend is en dat dit tot voorkeurbehandeling van die een vakgebied ten koste van die ander kon lei. ${ }^{42}$

Die onafhanklikheid van die kultuurhistoriese museum is ook bevorder deur die gedagte van 'n opelugmuseum. Hierdie idee is geïnisieer deur die Genootskap Oud-Pretoria, wat oor die sloping van ou geboue in Pretoria bekommerd was. Die Genootskap wou graag 'n woonhuis vir die nageslag bewaar, soos die huis van die Portugese handelaar, Bras Perreira. In 1953 was dié huis, op die hoek van Skinner- en Paul Krugerstraat, die oudste huis in Pretoria. Die Stadsraad van Pretoria was ook ten gunste van dié projek en 'n stuk grond is opsy gesit vir die bou van 'n opelugmuseum. Hoewel die Transvaalmuseum bekend was daarmee dat die Genootskap hom vir die oprigting van 'n opelugmuseum beywer het, kon die Museum as gevolg van 'n tekort aan fondse in daardie stadium nie aan die projek deelneem nie.

Soos die planne vir die afskeiding van die kultuurhistoriese afdeling as onafhanklike museum gevorder het, het die noodsaaklikheid van 'n nuwe, funksionele gebou op 'n nuwe terrein duidelik geword. Voorwerpe is ingesamel wat by 'n opelugmuseum gebruik kon word. Die Transvaalmuseum en die Genootskap het in gesprek getree en die toenmalige Minister van Onderwys, Kuns en Wetenskap is geraadpleeg. Hy het dit goedgedink om in 1960 'n Kommissie van Ondersoek na Openbare Museums in Pretoria aan te stel. Die Kommissie het volgens die verslag van 1961 bevind dat die enigste oplossing vir die probleem 'n onafhanklike kultuurhistoriese museum, insluitend 'n opelugmuseum is, en het 'n nuwe gebou aanbeveel. Die Booysen-komitee (Komitee van Ondersoek na die Behoeftes van Staatsondersteunde Inrigtings) van 1960 het in sy hoofverslag van April 1962 aanbeveel dat die kultuurhistoriese afdeling van die natuurhistoriese afdeling in 'n onafhanklike museum afgeskei moes word. Hoewel akkommodasie buite die Komitee se opdrag geval het, is ' $n$ aanbeveling wel gemaak dat dit onmiddellik aandag moes geniet.

In die Transvaalmuseum was een van die belangrikste besprekingspunte watter afdelings (kultuurgeskiedenis, antropologie en argeologie) na 'n onafhanklike kultuurhistoriese museum oorgeplaas moes word. Die rede hiervoor was dat antropologie gewoonlik as deel van die natuurhistoriese museum beskou is. Na haar

42 NKM, Argief, Stelsel 2 No 38 NKO(1) 1955-1970, Memorandum vir voorlegging deur die Historiese Genootskap van Suid-Afrika aan Sy Edele die Minister van Onderwys, Kuns en Wetenskap. 
aanstelling in 1953 het Roodt-Coetzee verantwoordelikheid vir al drie afdelings aanvaar en dit was vir haar logies dat al drie oorgeplaas moes word. Sy het geargumenteer dat 'n kultuurkundige museum etnologiese, argeologiese en kultuurhistoriese materiaal versamel as dokumente of getuienis wat in wetenskaplike navorsing oor die groepe in Suid-Afrika in voorhistoriese en historiese tydperke gebruik kon word. Haar standpunt dus was in direkte teenstellling met die algemene praktyk. Die drie afdelings het die kern gevorm van die nuwe Nasionale Kultuurhistoriese en Opelugmuseum.

Van April 1963 af is die kultuurhistoriese afdeling, bestaande uit kultuurgeskiedenis, etnologie en argeologie beheer deur die nuwe Historiese Subkomitee, wat nou meer gesag en 'n afsonderlike begroting gekry het, maar nog onder die Raad van die Transvaalmuseum geressorteer het. Dit was nogtans eers op 1 Augustus 1964 dat die amptelike skeiding tussen die twee museums in die Staatskoerant No. 881 van 1 Augustus 1964 geproklameer is. Die kennisgewing het gelui:

(a) die Kultuurhistoriese Afdeling van die Transvaal-Museum (bestaande uit die Ou Museum, die Paul Krugerhuis en 'n opelugmuseum wat in Pretoria opgerig sal word) as die Nasionale Kultuurhistoriese en Opelugmuseum, Pretoria, bekend sal staan; en

(b) die Natuurhistoriese Afdeling van die Transvaal-Museum (bestaande uit die Nuwe Museum en die Janse-Entomologiese Museum) as die TransvaalMuseum bekend sal staan. ${ }^{43}$

Op 1 April 1965 is Kotie Roodt-Coetzee as die eerste direkteur van die Nasionale Kultuurhistoriese en Opelugmuseum aangestel [Fig. 8] en is die kroon op baie jare van toegewyde arbeid op kultuurhistoriese en museumkundige gebiede gespan.

Sy het nie net daarin geslaag om 'n selfstandige instansie tot stand te bring nie, maar het die museologiese beginsels gevestig wat vir die uitbou van dié nuwe Museum noodsaaklik was. Die Museum het reeds beskik oor 'n groot versameling kultuurhistoriese voorwerpe, wat deur haar kundigheid en ywer bymekaar gebring is. In die toekoms sou 'n groot deel van haar werksaamhede op die totstandkoming van 'n opelugmuseum gerig wees. Hoewel terrein na terrein ondersoek is, is hierdie ideaal nie in haar ampstermyn bereik nie. Die Pioniersopelugmuseum - nie 'n opelugmuseum in die ware sin van die woord nie, maar eerder ' $n$ terreinmuseum - het wel onder haar leiding tot stand gekom. Onderhandelings is deur haar onderneem vir die verkryging

43 Transvaalmuseum, Jaarverslag 1964-1965, p. 8. 
van die grond waarop die Willem Prinsloo Landboumuseum ontwikkel is,. By haar aftrede in 1978 kon sy met trots op 'n loopbaan met baie hoogtepunte terugkyk en is sy in 1990 met die Orde vir Voortreflike Diens, Silwer, deur die Staatspresident vereer.

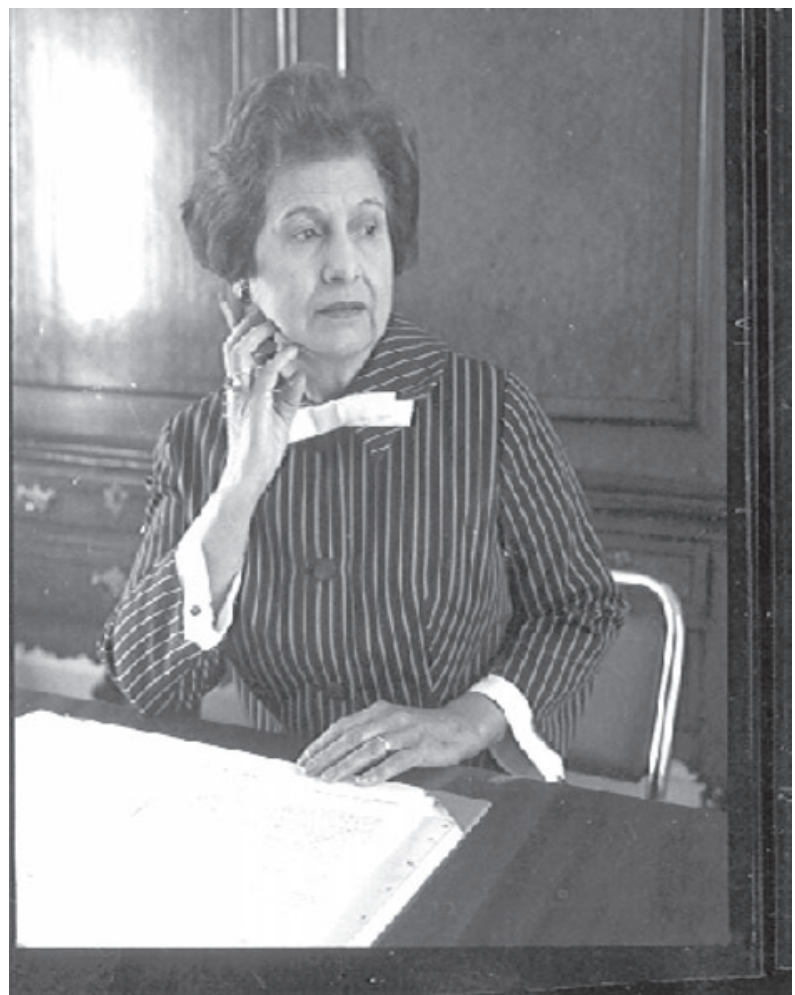

Figuur 8: Coetzee, direkteur van die Nasionale Kultuurhistoriese en Opelugmuseum, ca. 1970

(Nasionale Kultuurhistoriese Museum, Kotie Roodt-Coetzee Argief, Doos 37) 